ГЕОІНФОРМАЦЙНІ ТЕХНОЛОГІї GEOINFORMATION TECYNOLOGIES

УДК 574.5:004.4 (1-923)
УКРАЇНСЬКИЙ АНТАРКТИЧНИЙ ЖУРНАЛ

УАЖ № 9, 271-286 (2010)

\title{
MODELING OF STRUCTURE AND FUNCTIONS OF ANTARCTIC ECOSYSTEMS WITH THE HELP OF GIS-TECHNOLOGIES
}

\author{
Tashyrev O.B. ${ }^{1}$, Kobzar L.I. ${ }^{2}$, Usenko V.P. ${ }^{3}$, Morgun S.I. ${ }^{4}$, Seredynin E.S. ${ }^{4}$ \\ Danilo Zabolotny Institute of Microbiology and Virology NAS of Ukraine, 03143, Kyiv 143, \\ Academic Zabolotnystr., 154, tach2007@ukr.net \\ ${ }^{2}$ National Antarctic Scientific Center, 01601,Kyiv, T. Shevchenko bvld., 16, lina_kobzar@mail.ru \\ 3 Institute of Geological Sciences NAS of Ukraine, 01054, Kyiv, Gonchara str., 55-6, \\ vpu@voliacable.com \\ ${ }^{4}$ CJSC «ECOMMCo», 03115, Kyiv, Anatoly Petritskystr., 4, sm@ecomm.kiev.ua
}

Реферат. У статті представлено основні підходи до моделювання екосистем за допомогою GIS-технологій. Показано, що геоінформаційні системи дозволяють зберігати, систематизувати за просторовим принципом і аналізувати інформацію, яка стосується біотичних та абіотичних параметрів екосистем. Описано методики моделювання рельєфу земної поверхні, довготривалого моніторінгу структури та функціонування екосистем, створення моделей екосистем нижчих ієрархічних рівнів. Намічено шляхи подальшого розвитку методів збору та аналізу даних. Створено моделі стійкості мікроорганізмів до токсичних металів на біогеографічному полігоні о. Галіндез (Galindez), моделі розподілу пігментованих форм та співвідношення кількості пігментованих і непігментованих мікроорганізмів у скельних біоценозах. Використання GIS-технологій дозволило продемонструвати широке розповсюдження металрезистентних мікроорганізмів на біогеографічному полігоні, їх присутність у мохах, озерних мулах, грунтах, а також наявність пігментованих форм бактерій, мікроміцетів, дріжжів у біоценозах вертикальних скель. Показано, що використання GIS-технологій дозволяє виявити ділянки, найбільш перспективні для пошуку продуцентів біологічно активних речовин.

Ключові слова: ГIC, ArcGIS, моделювання, антарктичні екосистеми, екстремофільні мікроорганізми.

Реферат. На сегодняшний день комплексное изучение природы Антарктики является приоритетным направлением исследований. Однако моделирование структуры и функций экосистем по-прежнему далеко от завершения и поэтому остается стратегически важным. Оптимальным средством моделирования являются геоинформационные системы. Они позволяют обобщать информацию по пространственному принципу и автоматически включать в комплексный анализ широкий спектр абиотических параметров (высоту над уровнем моря, экспозицию, уклоны и т.д.). Целью работы является усовершенствование методических подходов для систематизации и анализа информации по биотическим и абиотическим параметрам, моделирования антарктических экосистем средствами GISтехнологий.

Моделирование экосистем осуществлялось в два этапа. На первом этапе выполнялись работы по созданию точной модели рельефа о. Галиндез (Galindez). Для моделирования земной поверхности использованись карты, 3D-модели рельефа и растровые фотоснимки, созданные специалистами ЗАО ЕСОММ и Национального антарктического научного центра (в 
Tashyrev O.B.. MODELING OF STRUCTURE AND FUNCTIONS OF ANTARCTIC ECOSYSTEMS WITH THE...

2002-2004 г., 2009 г.). На втором этапе осуществляется визуализация значений и трендов изменения биотических и абиотических параметров. Для сбора соответствующей информации в пределах зоны внутреннего островного шельфа (размером 30 х 60 км) и на о. Галиндез проводится комплексный мониторинг параметров экосистем. Отбор образцов выполняется по сети точек постоянного наблюдения (более 200 точек), точно позиционированных на местности. Затем происходит изучение образцов биологами, химиками, геологами. Полученные качественные и количественные характеристики хранятся в таблицах геобазы данных в составе геоинформационной системы ArcGIS от компании ESRI. Визуализация полученных данных осуществляется средствами приложения ArcMap c расширением 3D Analyst, изображения накладываются друг на друга в виде слоев.

Для удобства обработки данных нами введено понятие «локальная экосистема». Это природная система, включающая биотические и абиотические компоненты, количественные и качественные характеристики которой получены при изучении одного образца. B GIS параметры локальных экосистем привязываются к точечным объектам, не имеющим площади. Модель локальной экосистемы - это точка отбора образцов с визуализированной биологической информацией, нанесенная на карту, поверхность TIN, географически привязанную растровую фотографию. Модели включают такие слои: модель земной поверхности, структурные элементы ландшафта (микроозера, растительные сообщества), точки отбора образцов. Результаты анализа образцов (например, показатели устойчивости микроорганизмов к токсичным металлам) изображаются соответствующими символами на точках отбора. Модели отражают связи между живыми организмами, их устойчивость к экстремальным абиотическим факторам; размещение локальных экосистем по отношению к другим пространственным объектам, высоту экосистем над уровнем моря, ориентацию по сторонам света и крутизну склонов, на которых расположены локальные экосистемы, и т.д. Такой способ моделирования позволяет выявлять и наглядно отображать связи между изучаемыми параметрами.

Нами созданы 3D-модели и карты распределения микроорганизмов, устойчивых к токсичным металлам (ртуть, хром, кадмий, медь и др.) на биогеографическом полигоне о. Галиндез. Они демонстрируют высокую устойчивость микроорганизмов к токсичным металлам, широкое распространение металлрезистентных микроорганизмов на биогеографическом полигоне, их присутствие в мхах, лишайниках, озерных илах, почве. Созданы также модели распространения пигментированных форм микроорганизмов в наскальных биоценозах. Они позволяют сравнить количество дрожжей, микромицетов, бактерий в различных образцах, показать наличие и распределение пигментированных микроорганизмов. Указаные модели могут использоватся для выявления участков, наиболее перспективных для выделения промышленно перспективных микроорганизмов.

В дальнейшем планируется обобщение данных точечных замеров и создание моделей природных комплексов, имеющих площадь (элементарных ландшафтов, экосистем). Выделение элементарных ландшафтов будет осуществляться с использованием данных по характеру рельефа, типам горных пород, ландшафтообразующим видам и другим структурным характеристикам природных систем. Планируются создание классификации элементарных ландшафтов с использованием факторально-экологических матриц, детальное картирование элементарных ландшафтов. Это позволит полностью разделить территорию о. Галиндез на пространственные единицы, структурные и функциональные характеристики которых впоследствии будут сопоставляться между собой. Развитие сети точек постоянного наблюдения целесообразно осуществлять с использованием карты элементарных ландшафтов.

Изучение выделенных элементарных ландшафтов будет осуществляться с использованием экосистемного подхода, при котором особое внимание уделяется закономерностям функционирования природных систем. Это позволит установить функциональные связи между 
Tashyrev O.B.. MODELING OF STRUCTURE AND FUNCTIONS OF ANTARCTIC ECOSYSTEMS WITH THE...

экосистемами различных иерархических рангов. В результате будут созданы теоретические модели структуры и функций интегрированных макросистем, включающих несколько взаимодействующих элементарных ландшафтов. Эти модели продемонстрируют влияние живых организмов на глобальные биогеохимические циклы и векторные потоки элементов в Антарктике, позволят оценить воздействие глобальных климатических изменений на антарктические экосистемы.

В настоящее время на о. Галиндез проводится изучение ландшафтных комплексов различных рангов методом ландшафтного профилирования. В 2008 г. нанесены на карты отдельные компоненты ландшафтного комплекса о. Галиндез (макроландшафта). Ближайшей стратегически важной задачей является создание точной крупномасштабной биогеографической карты полигона о. Галиндез. Такая карта позволит приступить к созданию прогностических интегрированных моделей наземных экосистем на всех иерархических уровнях их организации.

Ключевые слова: ГИС, ArcGIS, моделирование, антарктические экосистемы, экстремофильные микроорганизмы.

\begin{abstract}
The article presents main approaches to ecosystem modeling with using of GIStechnologies. It was shown that geoinformation systems allow to store, systematize on the spatial principle and analyze information related to biotic and abiotic parameters of ecosystems. Methods of long-termed monitoring of ecosystem structure and functioning, earth surface relief modeling, developing models of ecosystems of lower hierarchical levels were described. Ways of further development of methods for collecting and analyzing data were contemplated. Models of the microorganisms resistance to toxic metals on the biogeographical polygon on island Galindez and models of pigmented forms distribution and a ratio of quantity of pigmented to non-pigmented forms of microorganisms in rock biocoenoses were created. Wide distribution of metal-resistant microorganisms on the biogeographical polygon, their presence in mosses, lichens, sludge, soil and presence of pigmented forms bacteria, micromycetes, yeasts in biocenoses of vertical cliffs were shown. It was shown that usage of GIS-technologies allows to identify the areas, which are the most perspective for searching of producers of biologically active substances.
\end{abstract}

Key words: GIS, ArcGIS, modeling, Antarctic ecosystems, extremophilic microorganisms.

\title{
1. Introduction
}

Owing to unusual geographical location of the continent, Antarctic ecosystems have unique properties, such as wide spectrum of extreme abiotic factors, high resistance of organisms to their actions, low species diversity and accordingly simplified structural-functional organisation. This means that ecological relationships between separate groups of living organisms are more clearly defined and more accessible for research than in ecosystems of other continents. Therefore, Antarctic ecosystems - very felicitous object for researching and modeling different natural phenomena and processes, such as complex resistance of living organisms to extreme abiotic factors influence, as well as global climatic changes influence on ecosystems.

To date the complex research of Antarctic nature is a priority direction of investigations, including SCAR projects (Polar Research..., 2008). Classification of Antarctic continental ecological environments, in which geological and climatological data are generalized, was devised by New Zealand scientists (Morgan et al., 2007). Regional classifications can be combined with continental classification for the purpose of its detailing and informativity increasing. However, detailed landscape-climatic investigations for the present are rare. In order to receive new data, a comprehensive research of natural-territorial complexes (landscapes) on is. Galindez is carried out.

The using of a systems approach during the Antarctic nature studding is typical for works of many biologists, however modeling of ecosystems structure and functions as before is not 
consummated and therefore is strategically significant (Polar Research..., 2008). The main goals of biological investigations of National Antarctic Scientific Center of Ukraine (NASC) are a complex research of Antarctic biota, impact of abiotic factors on it and impact of Antarctic biota on biogeochemical cycles. The last goal is very important as far as global warming and anthropological impact on Antarctic nature can lead to change of trends and Antarctic ecosystems evolutionary rate, level of biogeochemical activity of organisms (Красилов, 1994, 2001; Жерихин, 2003; Бурковский, 2006). Especially actual is a research of structure and functions of microbial communities, their resistance because biogeochemical cycles are fulfilled by microorganisms (Заварзин, 1993, 2004).

For developing of a complex characteristic of Antarctic ecosystems (landscapes) it is necessary to generalize data about abiotic factors (climatological, geographical, geological etc.) and structure and functions of biocenoses. These include the microorganisms resistance to action of extreme factors, their species composition, distribution, population characteristics. At complex analysis it is important to take into account the geographical attitude of points and objects (e.g. islands, areas with different vegetation types etc.) where measurement or sampling was carried out.

Therefore, the most optimal method of obtained data systematizing is geoinformation systems. They can be used for information storage, allow to generalize data by spatial principle and create integrated multilevel models of Antarctic ecosystems (Zeiler, 1999; Построение баз..., 2002; ArcGIS 9. ArcMap..., 2006). An application of GIS-technologies will provide carrying out of complex scientific researches by Ukrainian scientists at the level of international standards (Исследования..., 2008).

The purpose of the work is methodological approaches improvement for systematization and analysis of information on biotic and abiotic parameters, Antarctic ecosystems modeling with the help of GIS-technologies.

\section{Materials and methods}

\subsection{Area of investigations}

The main objects of the complex research are Antarctic terrestrial ecosystems (landscapes). There were separated out three fixed areas of investigation: 1) zone of inner island shelf $(30 \times 60 \mathrm{~km})$; 2) is. Galindez; 3) the biogeographical polygon on is. Galindez (fig. 1).

Zone of inner island shelf is a part of western shore of Antarctic peninsula and its inner island shelf from is. Cruls to cape Rassmussen from west to east and from is. Booth to is. Lippmann from south to north. It includes 14 islands and 3 objects on Antarctic peninsula shore: cape Tuxen, cape Rasmussen and mountain Waugh.

Island Galindez (fig. 1, b) is the main polygon of ecosystem (landscape) researches. Structural and functional relationships in biocenoses of island, abiotic factors (relief, hydrological regime, climate, geological material and substrata composition, etc) are investigated. Representative parts of island were described in the capacity of model ecosystems.

The biogeographical polygon is situated on is. Galindez on northern, the most warm, cliff. It includes Antarctic subpolar oasis with high biodiversity and a part of relict glacial top of is. Galindez with algal-bacterial criocenoses (fig. 1-4).

\subsection{Monitoring of ecosystems parameters}

In the range of inner island shelf zone a complex monitoring of ecosystems parameters (climatic factors, composition of rocks and soil-like substrata, abundance, species composition, population characteristics) is carrying out. Selection of native samples is implementing on net of points of regular monitoring. Laying of points began in 2002, now net includes more than 200 points (fig. 2). With the help of GIS-technologies points, which situated on the biogeographical polygon, are positioned accurate within $1 \mathrm{~m}$. Some of them are marked with pales with numbers. On the station and after transportation to Ukraine research of samples is carrying out by biologists, chemists, geologists 
Tashyrev O.B.. MODELING OF STRUCTURE AND FUNCTIONS OF ANTARCTIC ECOSYSTEMS WITH THE...

and other. Studding of landscape complexes of different ranks by landscape profiling method on is. Galindez is carrying out by us from 2004. At that relief, vegetation, soil and deposits also are described.

\subsection{Storage and visualization of received information}

Obtained quantitative and qualitative characteristics are held in geobase table data as a part of geoinformation system ArcGIS from company ESRI. Tables include 2 data types: spatial information, connected with two-dimensional and three-dimensional coordinates and information about attributes (properties, signs) of spatial objects (points, lines, polygons) (ArcGIS 9. ArcCatalog..., 2002; ArcGIS 9. ArcMap..., 2006). Attributive information includes a complex description of points of sampling, quantitative and qualitative characteristics of biota components, images and other.

Visualization of the attribute information is carried out with the usage of application ArcMap with extension 3D Analyst. Received images are superimposed on each other as layers, which allow modeling of structure and functions of ecosystems. Models include such layers: model of the earth's surface, structural elements of landscape, points of sampling. Results of samples analysis (e.g., parameters of microorganisms resistance to toxic metals) are represented by appropriate symbols on the points of sampling (fig. 3-5). For visualization of quantitative information are used proportional symbols (cylinder, bar charts), whose size depends on the value of the attribute (fig. 3; 4; 5, c, d). Qualitative information is transmitted by unique symbols, for example, geometric figures of two or three types (fig. 2; 3, b). Some information (e.g., points of sampling number) is visualized with inscriptions and annotations (fig. 3, b; 4; 5). For creation of complex inscriptions a standard facility ArcMap - VBA expression constructing - is used (Zeiler, 1999; ArcGIS 9. ArcMap ..., 2006). Whereas data on number of microorganisms in samples have a considerable scatter (from $10^{1}$ to $10^{8}$ cells/g of a sample), to construct easily-visible diagrams they are ranked accordingly to the order of their concentration in samples.

\subsection{Modeling of the earth surface}

For modeling of the earth's surface we use maps, 3D-models of relief and raster images (Zeiler, 1999). Maps of is. Galindez and the biogeographical polygon were created by CJSC ECOMM and National Antarctic Scientific Center in 2002-2004. Field GPS-observations and cosmic snapshots were used (ArcGIS 9. ArcMap ..., 2006). The first large-scale (1 : 250) topographic map of the biogeographical polygon was created in 2004 by a leading specialist of company ECOMM D. A. Myzin during the IX Ukrainian Antarctic Expedition (UAE). Points of sampling and geodesic fixed on the ground points of a basic network were mapped. Horizontal positioning accuracy equal to $2.5 \mathrm{~cm}$, vertical $-7-15 \mathrm{~cm}$.

3D model of the biogeographical polygon relief was developed on the same data array as topographic map. It was obtained by triangulation - componentry of triangles net, which connect points, coordinates of which were determined with the help of GPS. Continuous surface in threedimensional space - triangulation net (TIN) (fig. 1, c) - was obtained with the usage of ArcGIS (application ArcMap with extension 3D Analyst). During modeling of ecosystem parameters TIN was visualized by hillshading (fig. 1, a, b; 3, a) and color scale, which shows altitude range (fig. 4) (Zeiler, 1999; Бут, 2002).

At modeling of the earth's surface also was used a geographical anchor of raster image of cliffs of model ecosystem "Skalodrom-2" (fig. 5). For that geographical coordinates of a reference point, situated on the top of rock, were determined. Distances from a reference point to some other points (well visible on rock and situated in one photographing plane) were measured on the terrain.

Then to ArcGIS (application ArcMap) was downloaded a file, which contained a basic point. Other points were placed with the help of measured distances. Obtained by calculations points had virtual coordinates, whereas axis $\mathrm{z}$ for them becomes axis $\mathrm{y}$. To placed points, as to reference points with known coordinates, were snapped photos of vertical rock. That allowed obtaining of oriented to 
Tashyrev O.B.. MODELING OF STRUCTURE AND FUNCTIONS OF ANTARCTIC ECOSYSTEMS WITH THE...

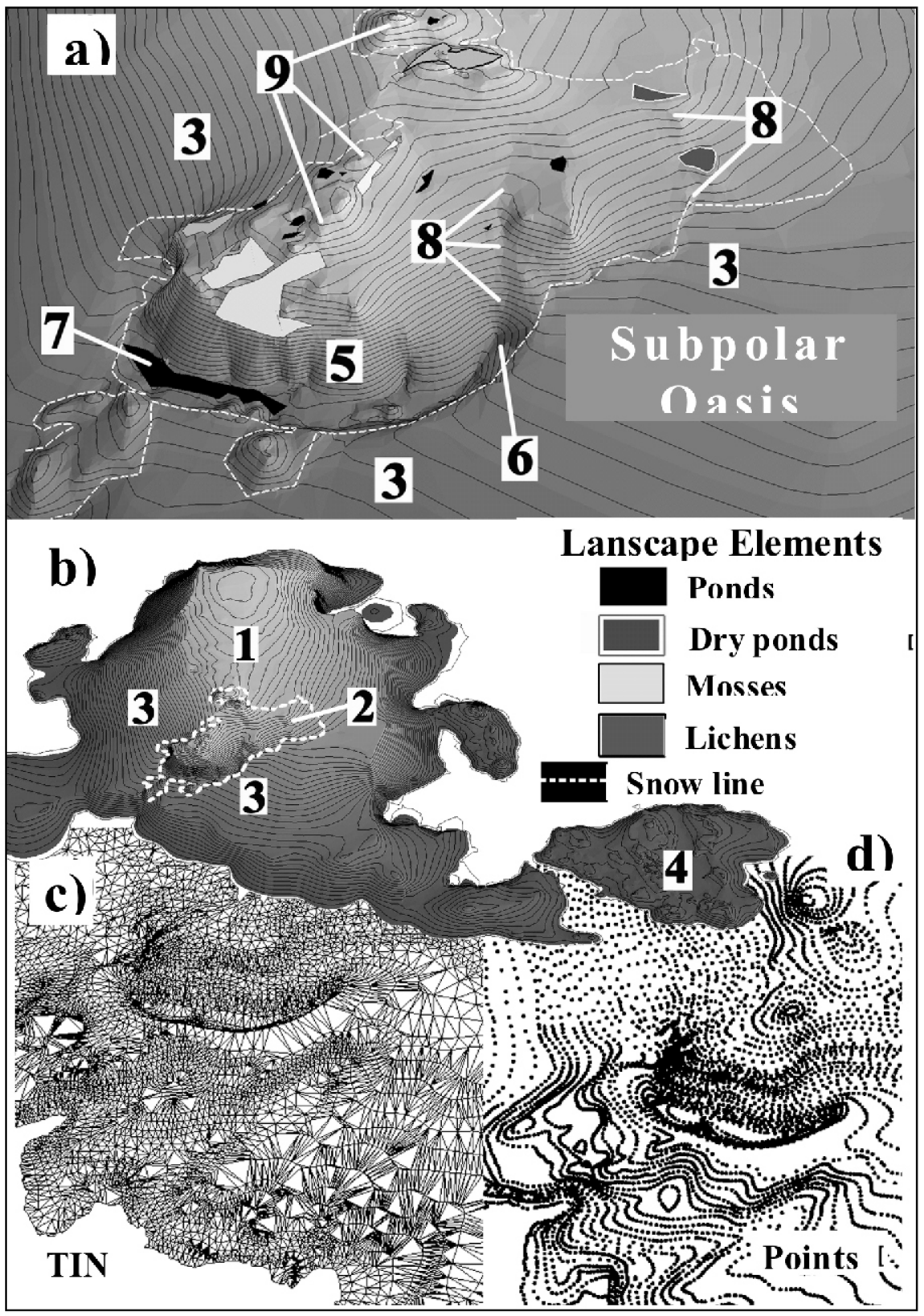

Fig. 1. The biogeographical polygon on is. Galindez: a) subpolar oasis; b) is. Galindez; c) triangulation net; d) points with measured coordinates $\mathrm{x}, \mathrm{y}, \mathrm{z}$.

Components of landscape system of the polygon: 1 - glacier "Domashniy"; 2 - subpolar oasis; 3 - snowfields; 4 - location of Ukrainian Antarctic station Academic Vernadsky;

5 - subvertical rocky surface; 6 - soils; 7 - base pond "Duga"; 8 - transit canals of localized substance drain; 9 - watershed.

Model ecosystems: 1, 3 - snow-ice; 5 - rocky; 6 - edaphic. 
Tashyrev O.B.. MODELING OF STRUCTURE AND FUNCTIONS OF ANTARCTIC ECOSYSTEMS WITH THE...

coordinates rock plane.

\subsection{Determination of geographical coordinates of points}

To obtain maps and 3D-models works on creation of two high-precision baseline geodetic networks of is. Galindez in whole and of the biogeographical polygon particularly ware carried out by specialists of CJSC ECOMM and National Antarctic Scientific Center during VII and VIII UAE (2002 and 2003). Works were carried out in two stages.

At the first stage coordinates of the reference point (marker point) "SCAR GPS" in the international system reference ellipsoid WGS84 with an accuracy of $5 \mathrm{~mm}$ were determined. For this purpose dual-frequency receivers Trimble GPS Total Station 4700 and Trimble GPS Total Station 4800 were used.

At the second stage geodesic GPS-survey with the usage of single-frequency receivers 4600 LS Surveor and Pathfinder ProXRS was carried out. At a static survey observations were carried out on stations within 1-72 hours (depending on the type of reference point). As the base station was used a dual-frequency GPS-receiver, mounted on the marker point with known coordinates. It determined coordinates of the marker point every second during the whole period of work. This allowed to estimate the inaccuracy of single-frequency GPS-receiver.

In the course of laboratory works at the Ukrainian Antarctic station Academic Vernadsky with the usage of software Trimble Geomatics Office and Pathfinder Office a differential correction of coordinates, received by field GPS-receptacles with the using of data from the base station, was carried out. This allowed to improve the accuracy of determinate coordinates up to $10 \mathrm{~cm}$ ("sabdecimetric" accuracy).

Determination of geographical coordinates of points of sampling on the biogeographical polygon on is. Galindez was carried out in a similar way with an accuracy of $1 \mathrm{~m}$. The most part of work was completed in 2006 and 2008 by specialists of CJSC ECOMM and National Antarctic Scientific Center. A portable field GPS-receiver GeoExplorer XT and a base station - a dualfrequency module GPS Trimble 4600LS, mounted on the marker point were used.

\section{Results and discussion}

A considerable part of the information was obtained by examining samples, which were taken from separate, precise positioned points. For convenience of data handling we have introduced the concept of "local ecosystem". This is a natural system, including biotic and abiotic components, quantitative and qualitative characteristics of which are obtained by studying a single sample. In GIS parameters of local ecosystems are linked to point objects, which have no square.

It is obvious that parameters values of local ecosystems can characterize whole natural territorial complexes (NTC). Characteristics (attributes) of these complexes can be obtained by generalizing of similar information from several points of sampling, which are located thereabouts. In GIS natural territorial complexes are represented as polygonal objects with a certain area. To describe such NTC it is advisable to use the concept of "elementary landscape". In our understanding - it is the smallest and the most simply constructed natural unit, which corresponds to one relief element, one kind of soil, one type of plant community, and, of course, one type of underlying rock. Species that are dominant at a certain area and are easily identifiable in nature are called landscape-formative (Галкин, 2002). These landscape-formative forms can be mosses, algae, lichens, vascular plants.

In the case of the usage terms "elementary landscape", "landscape" it always means a section with a certain area (a polygonal object on the map). The terms "local ecosystem", "ecosystem" are similar in meaning, but can designate as a natural geographical complex (polygonal object), and a system, corresponding to a point object on the map (e.g., bird's nest). Ecosystem is also sometimes means any system, including biotic and abiotic components (e.g, Petri dish with microorganisms) (Галкин, 2002; Заварзин, 2004; Бурковский, 2006). 
Tashyrev O.B.. MODELING OF STRUCTURE AND FUNCTIONS OF ANTARCTIC ECOSYSTEMS WITH THE...

The usage of the term "landscape" means "appearance" of a natural system. Therefore, the use of a landscape approach for the study of NTC of is. Galindez will enable a separating of individual natural units (elementary landscapes, ecosystems) in the field. Allocation will be carried out by using of data on topography, types of rocks, landscape-types and other structural characteristics of natural systems. Further study of elementary landscapes will be carried out with the usage of an ecosystem approach, which focuses on regularities of natural systems functioning (Галкин, 2002; Жерихин, 2003).

At the present time (2008) only separate components of a landscape complex of is. Galindez (macro-landscape) were mapped. In future developing of elementary landscapes classification with the use of factorial-ecological matrixes (Раменский, 1971; Брагин, 2005) and detailed mapping of elementary landscapes will be carried out. It will allow the complete separation of the island on spatial units (elementary landscapes, ecosystems), functional and structural characteristics of which in future will be compared against each other. In the sequel it is reasonable to carry out development of points network for incessant control with the use of elementary landscapes map.

\subsection{Main approaches to modeling of structure and functions of ecosystems with the help of GIS-technologies}

The structure of ecosystems corresponds to ensemble of smaller units (subsystems), isolated by using of certain criteria. Structural parameters of an ecosystem - it's quantitative and qualitative

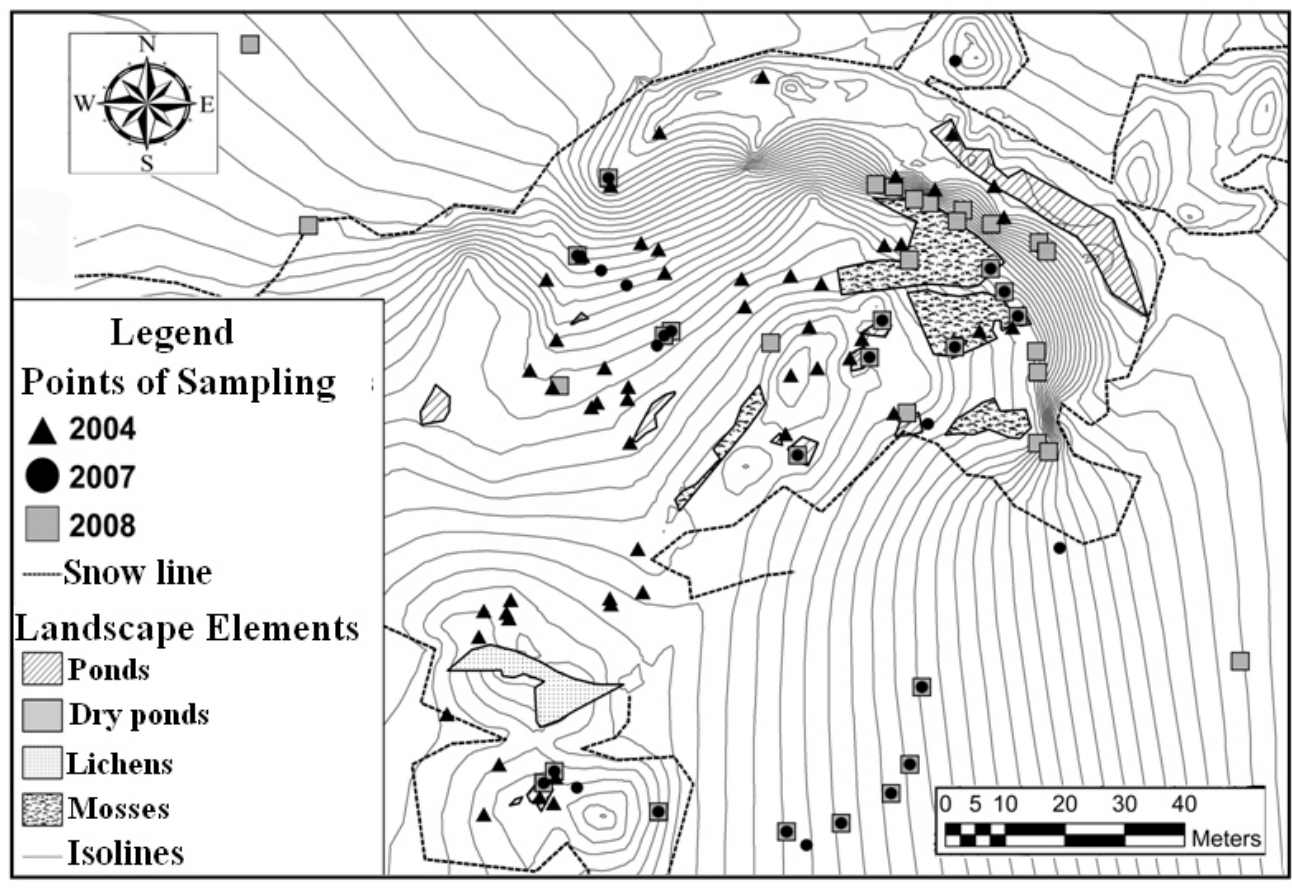

Fig. 2. Points of sampling on the biogeographical polygon on is. Galindez. 
Tashyrev O.B.. MODELING OF STRUCTURE AND FUNCTIONS OF ANTARCTIC ECOSYSTEMS WITH THE...

characteristics of its elements. These include: species composition, biomass, organisms resistance to the action of extreme factors, height above a sea level, amount of solar radiation, etc.

Ecosystem functions - its specific "activity" (production, consumption and decomposition of substance) that provides a flow of energy between different structures. The functional characteristics of ecosystem include the features of the biogeochemical cycles of elements: biological productivity, rate of biomass overturn, production of biogenic matter, etc. (Бурковский, 2006).

Under the model of some object is understood another object that is different from the original, but allows to distinguish the essential properties of the original object and to disclose them more fully. Important for modeling properties of the research object (ecosystem, elementary landscape) are: geographical location, height above sea level, size and shape, the values of biotic and abiotic parameters, etc.

Modeling of structure and functions of Antarctic ecosystems carry out with the usage of GIStechnologies. Geographical informational systems (GIS) are an ensemble of facilities (equipment, software, personnel), which provide input, storage, processing, visualization, modeling of spatial and associated attributive data (Zeiler, 1999; ArcGIS 9. ArcMap..., 2006).

Spatial information is information linked to two-dimensional or three-dimensional coordinates. Spatial objects - separated independent elements on the map. Small objects are represented as points (location of bird nests, point of sampling), elongated in the form of lines (boundary of snow). Large area objects - in the form of polygons (is. Galindez, the biogeographical polygon, places of animals assemblage, territories occupied by a certain type of vegetation). In addition to spatial information, GIS can store and process the attribute information - characteristics of spatial objects (data on the quantity and species composition of living organisms, their resistance to extreme factors, description of the sampling points, images) (Zeiler, 1999; Бут, 2002; ArcGIS 9. ArcCatalog..., 2002; ArcGIS 9. ArcMap..., 2006).

A set of tools in GIS makes possible visualizing of attributes of spatial objects, receiving of new information by means of creation inquiries to maps and mathematical calculations. For example, it is possible to compute area, which is occupied by some type of vegetation, a distance between determinate points, find an object by its location (Zeiler, 1999; ArcGIS 9. ArcCatalog..., 2002; ArcGIS 9. ArcMap..., 2006).

The using of a general spatial basis (model of the earth's surface) allows to demonstrate the distribution of any spatial objects, join attributive information of different quality. Application of GIS for modeling of biological processes automatically allows including of wide range of abiotic parameters (height above sea level, exposure, slope, etc.) to complex analysis and examining their impact on biocenoses. Thus, GIS-technologies are perfect for creating models of ecosystems structure and functions. Ecosystems modeling realizing in two stages: 1) creation of definite model of relief of investigated territory; 2) visualization of values and trends of abiotic and biotic characteristics changes.

Functioning of ecosystems includes internal and external components. It is connected with presence of functional subordination of ecosystems, their hierarchy. An internal component corresponds to processes, which occur in the limits of a given system. They sustain cycle of matter, provide integrity and stability. An external component - functional interaction with other ecosystems, sustaining integrity of more highly organized macrosystems (Бурковский, 2006). Accordingly, modeling of structure and functions of Antarctic ecosystems at two hierarchical levels: 1) local ecosystems (elementary landscapes); 2) integrated natural macrosystems, involving several interacting local ecosystems (in particular, the ecosystem of the Antarctic oasis on is. Galindez). The result will be the creation of theoretical integrated models of structure and functions of Antarctic ecosystems, which demonstrate the influence of living organisms on the global biogeochemical cycles and vectorial streams of elements. This article presents created by us models of local ecosystems of the biogeographical polygon on is. Galindez (fig. 3-5). 
Tashyrev O.B.. MODELING OF STRUCTURE AND FUNCTIONS OF ANTARCTIC ECOSYSTEMS WITH THE...

\subsection{Modeling of topographic base - the biogeographical polygon}

The biogeographical polygon is located on a north, turned to the sector of sun refulgence, slope of hill of is. Galindez (fig. 1-4). It is the subantarctic moist oasis. The polygon area is equal $0,073 \mathrm{~km}^{2}$, the highest point is $58 \mathrm{~m}$ above a sea level. The polygon is well warmed up, it is surrounded by glacial formations and snowfields on a perimeter. It's characterized by the presence of high-altitude zonality (vertical zonality), clearly expressed concentrated and plane substance drain, location in a narrow barrier stripe genetically different air masses (cold Antarctic and warm Pacific), and, as a result, high biodiversity and difficult landscape structure. On the polygon it is possible to observe and study unique processes of primary soil formation, destruction of rocky breeds, successive settling the rock surface by living organisms etc.

Coming from the tasks of concrete works, 3 model ecosystems were distinguished on the biogeographical polygon - snow-ice, rocky ("Skalodrom 1 and 2") and soil (fig. 1, a). Microorganisms of snow-ice communities carry out photosynthesis of organic compounds, participate in processes of biohumus formation on the snow surface, impact on balance of greenhouse gases. Vertical rocks (15$20 \mathrm{~m}$ high) are maximally subjected to the action of extreme factors: sharp daily temperature difference, drying, cyclic "freezing-thawing", UV-radiation, toxic metals etc. Rocks are covered by a heavy layer of biofouling and are a successful object for studding of mechanisms of multiple resistance of organisms to the wide spectrum of extreme factors. Soil organisms participate in vectorial streams of basic biogenic elements (carbon, nitrogen, phosphorus, sulphur etc.) and influence on functioning of ecosystems of higher hierarchical levels.

The models of the whole biogeographical polygon and large-scale models of its separate areas (vertical rocks) were created. Models include 2-7 layers, imposed on each other. A layer is a separate set of associate data (for example, layer of relief model, layer of structural elements of landscape, layer of snow bound, layer of isolines, layer of points of sampling etc.) (fig. 1-5). Layers are placed one over other, it is possible to enable and disable them, causing appearance and disappearance of objects on a map, that is very comfortably for the data investigation and creation of integrated models.

\section{Relief models of the biogeographical polygon}

The earth's surface can be designed in GIS in several ways: as an irregular triangulation network (TIN), as a set of isolines, and also as a raster image. The basic method of relief modeling and location of objects in GIS are maps, which transfer gigantic volumes of information. Maps are the main instrument for research of a spatial distribution of the objects, their placing on relative to each other (Zeiler, 1999; ArcGIS 9. ArcMap., 2006). A creation of large-scale topographical maps is especially important, as they are the most informing (Литвинов и др., 2006). We have developed the large-scale maps of subpolar oasis (fig. 2; 3, b) and is. Galindez. They allow exactly showing forms and sizes of objects, orientation on cardinal points and height above a sea level with the help of isolines, being in the distance one meter from each other.

3D-models of is. Galindez and the biogeographical polygon represent a triangulated irregular network (TIN) (fig. 1; 3, a). This is a continuous surface in three-dimensional space, consisting of triangles with common sides. At vertices of triangles are points, each of which corresponds to the height. Since the other two coordinates are not available, unlike maps, TIN can be swivelled, examining the shape of the earth's surface. Triangulation net models the surface with lines of inflection (streams, ridges), it cannot display negative biases (e.g., ledges, cornices, caves). 3D-model can be represented as a map of surface TIN, using the application ArcMap, if it is necessary to show the orientation by cardinal points (fig. 4; 5, b) (Zeiler, 1999; Бут, 2002).

On models TIN is shown with washing relief - darkening edges to create a realistic image of the surface (fig. 1, a, b; 3, a). Darkening effect is created by calculation, taking into account the position of the sun, which can be set. TIN surface can be visualized by using of colors, which show the range of heights (fig. 4), slopes, exposition (orientation by cardinal points). Using of 3D-model allows to calculate slope, exposure, height of each point, compute surface statistics (average slope, area, perimeter) (Zeiler, 1999; Бут, 2002). Mentioned features can be used for modeling, because slopes 
gradient, quantity of solar radiation and height above sea level impact on organisms communities.

\section{Basic structural elements of the biogeographical polygon landscape}

On 3D-models and maps of the biogeographical polygon are mapped such components of landscape system (fig. 1-4):

1. Glaciers: "upper" - glacier Domashniy; "inferior" - not great glacier, at the bottom of polygon cliffs.

2. Rocks (average slope at the top $-12-15^{\circ}$ at the bottom $-50-90^{\circ}$ ).

3. Microponds, an area of which is $2.5 \mathrm{~m}^{2}$. The largest pond "Duga" located at the base of the polygon in the thermal niche of the glacier. It is fed by melt water of ice cap of the island, oasis, part of the glacier adjacent to the cliff and precipitation.

4. Watershed of oasis.

5. Transit canals of localized substance drain. By them stones, gravel, remnants of vegetation move to pond situated at the base of the polygon.

6. Plant communities. Lichens are located at the top of the polygon, and mosses, Colobanthus quitensis, Deschampsia antarctica - at the bottom. Sometimes mossy fields cover large areas (10-30 $\mathrm{M}^{2}$ ), clumps (moss cushions) depth attains 60-70 sm. Under moss situated a soil-like substratum.

Microponds and plant communities applied on maps and 3D-model as new polygons with irregular shape. Attributive information is shown by symbols (filling with different pattern), unique to each class of polygons (ponds, drained ponds, lichen, moss).

\section{Model of ecosystem "Skalodrom-2" relief}

For modeling of vertical rocks relief were used raster images. Fig. 5 (b) shows a 3D-map of the model ecosystem "Skalodrom-2". Points of sampling in Groups 1 and 2 are arranged one above the other, i.e., have practically the same coordinates x, y. Differs only the coordinate z. Fig. 5 (b) shows that the usage of 3D-maps does not allow to "move apart" these points. The usage of TIN of polygon also failed because it did not have enough accuracy to show the features of the microrelief.

Therefore, to create a model the geographical anchor of raster image of a part of the earth's surface, where the model ecosystem "Skalodrom-2" is situates, was carried out (fig. 5, a, c, d). Only the top point in group 1 (Т-ск-1) has real coordinates, the other 11 points have conditional coordinates. The model does not reflect the rock orientation on cardinal points (north-south, east-west), because photography is rotated with respect to groups of points on the map to increase visibility.

However, the model shows the orientation of the "Skalodrom-2" by vertical (top-bottom) and horizontal (right-left). The model has a scale, on which all distances and proportions are observed. It enables showing of microrelief features without preliminary measurements, mutual arrangement of points of sampling. An interesting feature of this model is that unlike maps and TIN it allows to calculate the area of biofouling (fig. 5).

\section{Points of sampling}

Points of sampling on the biogeographical polygon models and ecosystem "Skalodrom-2" correspond to separate layers of spatial objects. On the fig. 2 all points, which were positioned in the same year, are marked by identical signs (circles, squares, triangles).

Attributive information of points includes numbers, descriptions, results of complex analysis (data on resistance to toxic metals, amount of pigmented and non-pigmented microorganisms, type of substrate etc). ArcGIS facilities allow to present on models of the earth's surface (maps, TIN) practically any attributes of points, both quantitative and qualitative indexes (fig. 3-5). Due to it models of local ecosystems were created.

\subsection{Visualization of attributive information}

A model of local ecosystem is a point of sampling with visualized biological information, inflicted on a map, surface of TIN, geographically linked raster photo (fig. 3, a). Models show the connections between living organisms, their resistance to extreme abiotic factors; placing of local ecosystems in relation to other spatial objects (areas covered with the certain type of vegetation, 


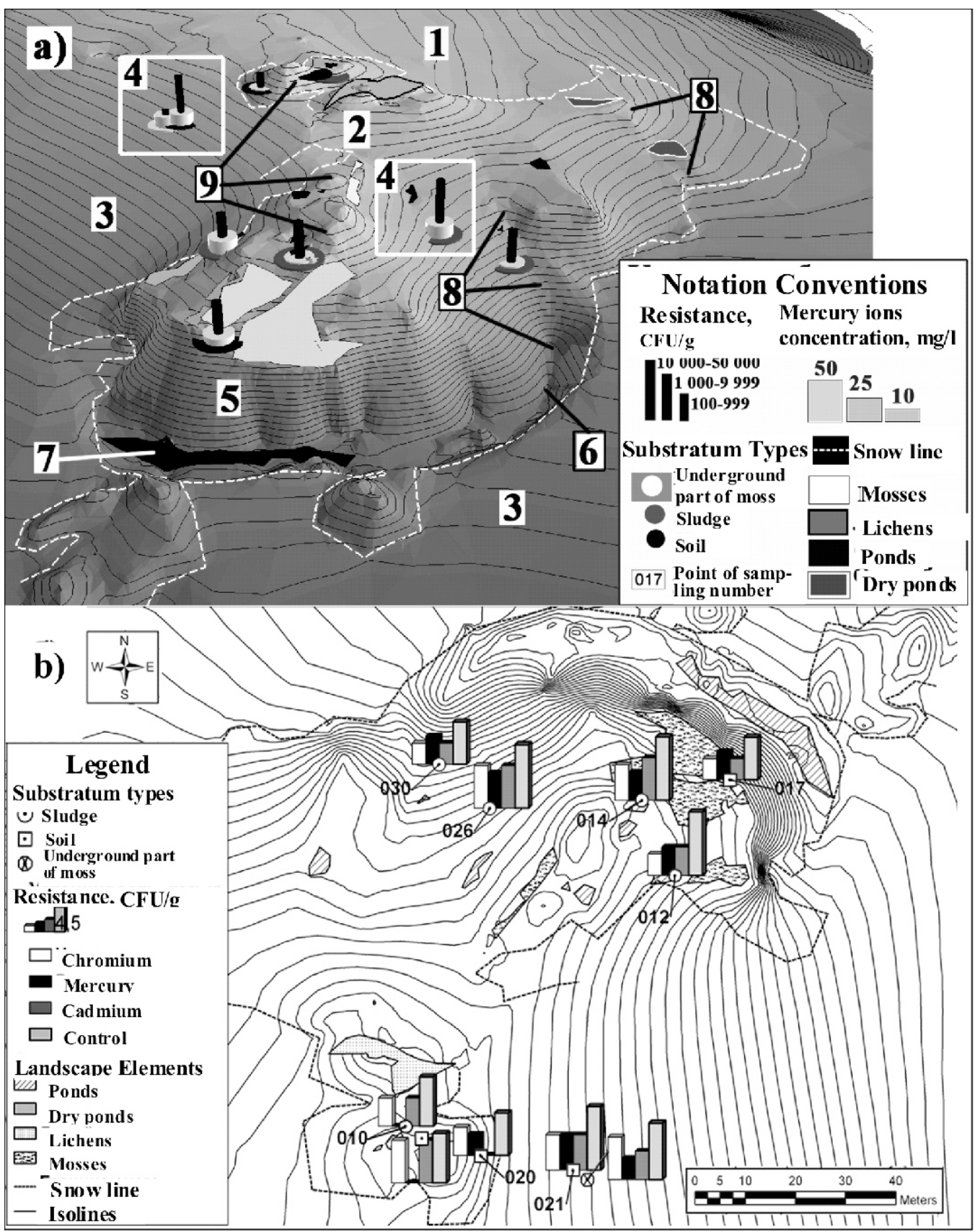

Fig 3. Microorganisms resistance to toxic metals on the biogeographical polygon on is. Galindez: a) resistance to mercury; b) polyresistance to toxic metals.

1 - glacier "Domashniy"; 2 - subpolar oasis; 3 - snowfields; 4 - model of local ecosystem; 5 - subvertical rocky surface; 6 - soil ecosystems; 7 - base pond "Duga"; 8 - transit canals of localized substance drain; 9 - watershed. 
Tashyrev O.B.. MODELING OF STRUCTURE AND FUNCTIONS OF ANTARCTIC ECOSYSTEMS WITH THE...

ponds, snow bound). Models reveal the height of ecosystems above a sea level, exposition and gradient of slopes on which local ecosystems are located etc. Such method of modeling allows detecting connections between separate parameters and evidently representing correlative dependences. Models of structural characteristics of local ecosystems are given below.

\section{Modeling of metal-resistant microorganisms distribution}

3D-models and maps of distribution of microorganisms, resistant to toxic metals (mercury, chrome, cadmium, copper) on the biogeographical polygon on is. Galindez (fig. 3, 4) were created by us. For this purpose by facilities of applications ArcMap and ArcScene on points of sampling such attributes were visualized: quantity of colony forming units per $1 \mathrm{~g}$ of a sample $(\mathrm{CFU} / \mathrm{g})$ in the presence of toxic metal and in control (without metals), concentration of toxic metal in medium, substrata type (sludge, soil and other), number of point of sampling.

Microorganisms resistance to metals $(\mathrm{CFU} / \mathrm{g})$ is shown on models by bar graphs and proportional symbols - cylinders with different height. For their construction data were ranged. For visualisation of substratum types were used symbols, which are unique for every class of objects (underground part of mosses, sludge, soil). These symbols are multicolored discs with the same diameter and various geometric figures. Numbers of points of sampling are shown with the help of inscriptions and annotations (Бут, 2002; ArcGIS 9. ArcMap..., 2006).

Obtained models of local ecosystems demonstrate a widespread of metal-resistant microorganisms on the biogeographical polygon, their presence in different habitats (mosses, lichens, pond sediment, soil). 3D-model of the microorganisms resistance to mercury (fig. 3, a) shows that the growth of microorganisms occurs at very high concentrations of this metal in the medium (50-100 $\mathrm{mg} / \mathrm{l} \mathrm{Hg} 2+$ ). Bar graphs provide an opportunity to compare microorganisms resistance to mercury, chromium, cadmium and growth of microorganisms in experiment and control (i.e. without metals) at different points of sampling (fig. 3, b). Furthermore, the usage of bar graphs demonstrates microorganisms polyresistance to toxic metals.

\section{Modeling of pigmented forms of microorganisms distribution in rocky biocenoses}

To obtain models by means of applications ArcMap and ArcScene on points of sampling were visualized such attributes: type of substratum (unique symbols), quantity of pigmented and nonpigmented forms of microorganisms (charts), number of point of sampling (inscription or annotation) (fig. 5).

A ratio of number of pigmented and non-pigmented organisms is shown in two ways: by means of bar and pie charts (Бут, 2002; ArcGIS 9. ArcMap..., 2006). To construct bar charts (fig. 5, c) data on different forms of microorganisms quantity were ranged. Bar charts allow to compare of the absolute number of different organisms (yeast, fungi, bacteria) in samples taken at several points, to show the presence and distribution of pigmented microorganisms in rock biocenoses.

At construction of pie charts ranking the data has not been applied (fig. 5, d). Pie charts show the quantitative ratio (expressed in constituents) of different forms of microorganisms from each point of sampling. They give an indication about relative distribution of various microorganisms. However, these diagrams do not allow comparing of absolute values of identical microorganisms quantity on several points. Pie charts can be used for identifying areas with the dominance of pigmented forms of microorganisms. These areas are the most promising for sampling in order to isolate strains of potential producers of biologically active substances (melanin, carotene, flavins, and several others). Pie charts show that on rock with relatively homogeneous abiotic conditions, biotic parameters of ecosystems can be very different (for example, the ratio of pigmented and non-pigmented microorganisms). 


\section{Conclusion}

Geoinformation systems - the most convenient tool for the systematization and analysis of biological, geological and geographical, geodetic information. Their use has allowed to create models of the earth's surface, to develop methods for long-term monitoring of ecosystems parameters, to formulate the basic approaches to modeling and to create a models of local ecosystems, to identify ways for further developing network of points of constant surveillance. With the help of GIStechnologies was demonstrated a widespread of metal-resistant microorganisms on the biogeographical polygon on is. Galindez, their presence in different types of habitats (mosses, lichens, pond sediments, soil), the distribution of pigmented forms of microorganisms in rock biocenoses. It is shown that the use of GIS allows to identify the most promising areas for the isolation strains, producing biologically active substances.

In future we plan to generalize data on dotted measurements and create models of natural systems, which have area, i.e., elementary landscapes (ecosystems). Relationships between distribution, population characteristics of Antarctic organisms, their resistance to a wide spectrum of extreme factors will be identified.

Research and modeling of processes, ensuring the cycling of elements in ecosystems are also in plans. This will allow determining of functional connections between ecosystems of different hierarchical ranks. Consequently theoretical models of structure and functions of integrated macrosystems will be created. With their help will be determined the role of ecosystems in global biogeochemical cycles and vectorial streams of elements in the Antarctic. Mentioned models are perspective for quantitative and qualitative assessment of global climate changes impact on Antarctic

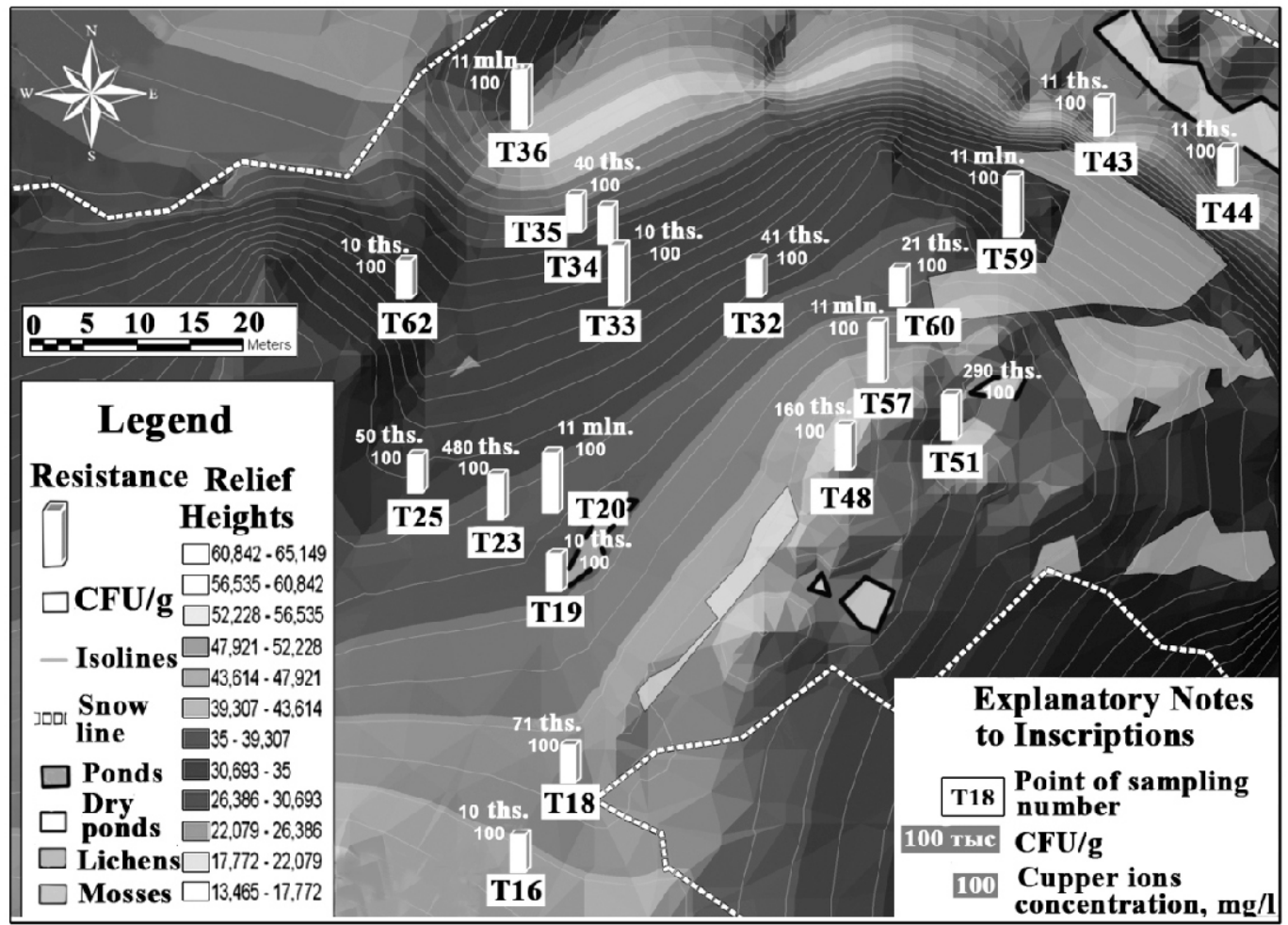

Fig. 4. Microorganisms resistance to copper on the biogeographical polygon on is. Galindez. 
Tashyrev O.B.. MODELING OF STRUCTURE AND FUNCTIONS OF ANTARCTIC ECOSYSTEMS WITH THE...

ecosystems.

Nearest strategically important task, follows logically from the presented material, is to create accurate large-scale biogeographical map of the polygon (is. Galindez). Such map will allow to start creating of predictive integrated models of terrestrial ecosystems at all hierarchical levels of their organization.

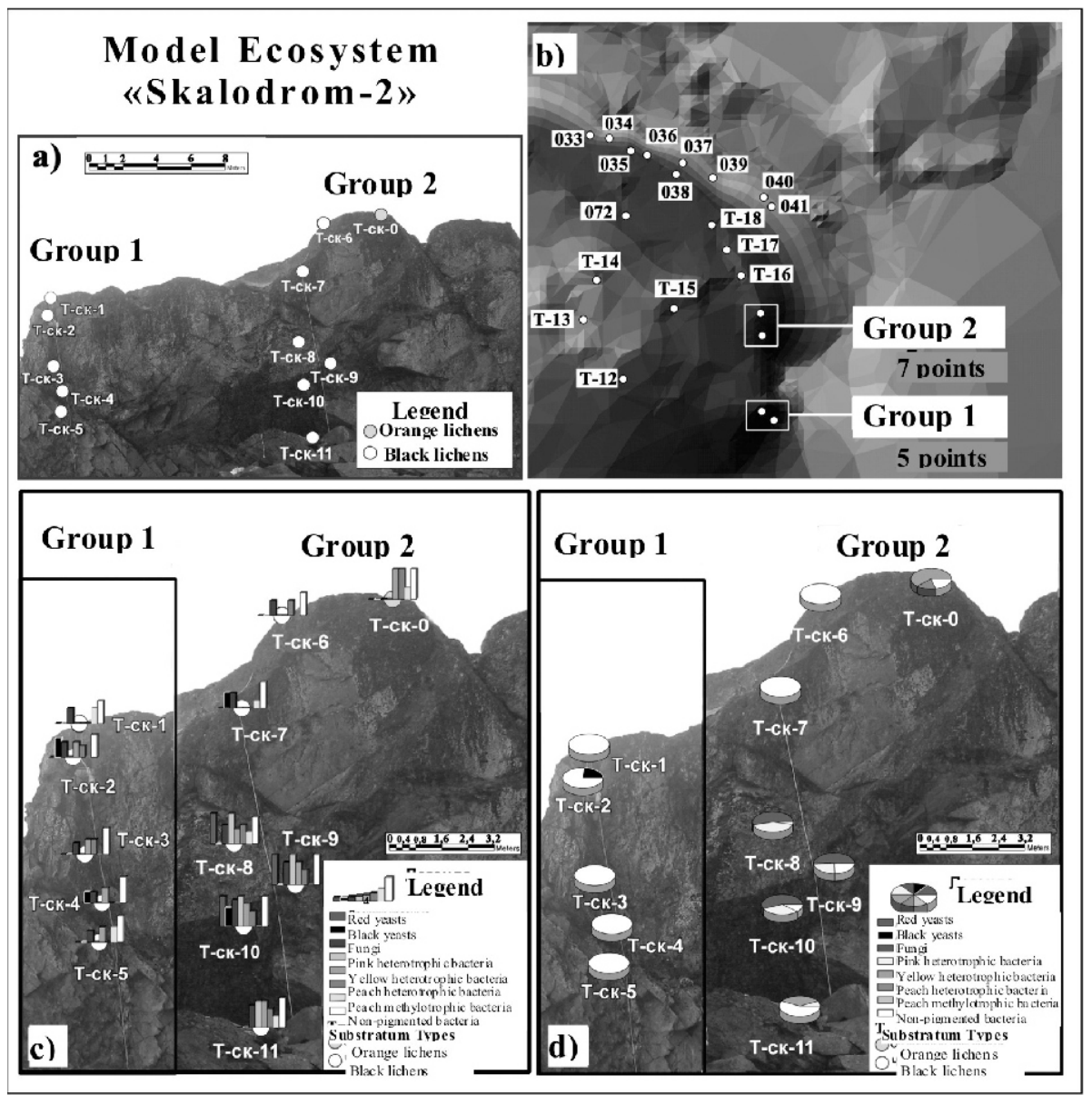

Fig 5. Model ecosystem "Skalodrom-2": a) points of sampling on "Skalodrom-2"; b) map of surface of TIN of the biogeographical polygon with groups of points; c) modeling of different types microorganisms quantity with the help of bar graphs; d) modeling of percentage ratio of microorganisms of different physiological and ecological-trophic groups with the help of pie charts. 
Tashyrev O.B.. MODELING OF STRUCTURE AND FUNCTIONS OF ANTARCTIC ECOSYSTEMS WITH THE...

\section{Literature}

ArcGIS 9. ArcCatalog. Руководство пользователя-M.: DATA+, 2002.-266 c.

ArcGIS 9. ArcМар. Руководство пользователя. -К.: ЕСОММ, 2006. -546 с.

Брагин П.Н. Морфодинамический анализ топологии ландшафта как базовая операция ландшафтного планирования: На примере подзоны южной тайги и урбанизированной территории г. Ярославля: Дис. ... канд. геогр. наук: 25.00.23. - Ярославль, 2005. - 186 с. - РГБ ОД, 61:05-11/144. - Режим доступа: http://www.lib.ua-ru.net/diss/cont/127309.html

Бурковский И.В. Морская биогеоценология. Организация сообществ и экосистем. М.: Т-во науч. изд. КМК, 2006. -285 с.

Бут Б. ArcGIS 3D Analyst. Руководство пользователя-М.: Дата+, 2002. -243 с.

Галкин С.В. Гидротермальные сообщества мирового океана. Структура, типология, география. -М.: ГЕОС, 2002.-200 с.

Жерихин В.В. Избранные труды по палеоэкологии и филоценогенентике / Ред. колл. Г. Ю. Любарский, К. Г. Михайлов, А. П. Расницын. -М.: Т-во науч. изд. КМК, 2003. -542 с.

Заварзин Г.А. Развитие микробных сообществ в истории Земли // Проблемы доантропогенной эволюции биосферы. - М.: Наука, 1993. - С. 212-222.

Заварзин Г.А. Лекции по природоведческой микробиологии / Отв. ред. Н. Н. Колотилова; Ин-т микробиологии. - М.: Наука, 2004. - 348 с.

Исследования Украины в Антарктике / Исследования Украины в Антарктике / Отв. ред. П.Ф Гожик, сост. В.П. Рыбачук, П Ф. Гожик, Н.Г. Виденина, В.А. Литвинов. - Киев, 2008. $286 \mathrm{c}$.

Красилов В.А. Глобальные климатические изменения как фактор эволюции биосферы // Экосистемные перестройки и эволюция биосферы. - М.: Недра, 1994. -C. 285-294.

Красилов В.А. Модель биосферных кризисов // Экосистемные перестройки и эволюция биосферы. Вып. 4. - М.: Издание Палеонтологического института, 2001.- С. 9-16.

Литвинов В., Глотов В., Колб І., Чижевський В. Аналіз картографічного забезпечення для створення ГІС Антарктичної станції Вернандського // Український антарктичний журнал. -2006. - № 4-5. - С. 14-20.

Построение баз геоданных. - М.: DATA+, 2002.-426 c.

Раменский Л.Г. Проблемы и методы изучения растительного покрова: Избр. работы. Л.: Наука, 1971.-334 с.

Morgan F., Barker G., Briggs C. et al. Environmental Domains of Antarctica. Version 2.0 Final Report. Landcare Research Contract Report: LC0708/055. Prepared for: Antarctica New Zealand Department of Conservation. - November, 2007.-89 p.

Polar Research - Arctic and Antarctic Perspective in the International Polar Year. SCAR/IASC IPY Open Science Conference: Abstract Volume. (St. Petersburg, Russia, July 8-11, 2008.) / Ed. A. Klepikov - St. Petersburg: Elektronstandart-Print Joint-Stock Company, 2008. - 502 p.

Zeiler M. Modeling Our World. The ESRI Guide to Geodatabase Design. - Redlands: Environmental Systems Research Institute, Inc., 1999. - 199 p. 